\section{特許 紹介}

溶解用クラフトパルプ製造工程の前加水分解蒸著廃夜 より結晶キシロースを製取する方法

特許出願公告 昭43-731

公告昭43.1.11

出 願人 日本パルプ工業株式会社

特許請求の範囲

1・本文に詳記した如くキシランを含有する植物繊維原 料から水蒸者前加水分解クラフト法により溶解用パルプ を製造する際の前加水分解蒸蒝廃液を原料として結晶キ シロースを製取するに当り，その精製工程において原料 たる前加水分解蒸煮廃液を常温または加熱下に紫外線を 照射しながら酸素がスまたは空気を吹き込久，着色不純 物を酸化変質せしめ水に不溶解物質として分離除去する ことを特徵とする前加水分解蒸著廃液より結晶キシロー スを製取する方法。

\section{生澱粉の処理方法}

特許出願公告 昭 $43-732$

公告昭43.1.11

出 願 人 株式会社パーマケム・アジア

特許請求の範囲

1 . 生溊粉に少量のアジ化アルカリ金属塩又はアジ化了 ルカリ土類金属塩の 1 種又は 2 種以上を添加することを 特徴とする, 生澱粉の処理方法。

\section{生澱粉処理剂}

\section{特許出願公告 昭43-733}

公 告 昭43.1.11

出 願 人 株式会社パーマケム・アジア 特許請求の範囲

1・アジ化アルカリ金属塩又はアジ化アルカリ土類金属 塩の 1 種又は 2 種以上と界面活性剤とを含有する生澱粉 処理剂。

\section{リン脂質加工澱粉の製造方法 \\ 特許出願公告 昭43-734 \\ 公 告 昭43.1.11 \\ 出 願 人 味の素株式会社 特許請求の範囲}

1. 澱粉とリン脂質とを該溉粉の糊化（又は $\alpha$ 化）転移 温度以下で接触反応せしめることを特徵とするリン脂質 加工潵粉の製造方法。
溶解用クラフトパルプ製造工程より結晶キシロース を製取する方法

特許出願公告 昭43-2749

公 告 昭43.1.31

出願人 日本パルプ工業株式会社 特許請求の範囲

1・本文に詳記したよ5にキシランを含有する植物繊維 原料から水蒸煮前加水分解クラフト法により溶解用パル プを製取する際に得られる前加水分解蒸薏廃液を後加水 分解し, しかる後精製濃縮の工程を経て含有するキシロ 一スを結晶状態で単離することを特徵とする溶解用クラ フトパルプ製造工程の前加水分解蒸煮廃液より結晶キシ ロースを製取する方法。

\section{澱粉加水分解物による無水デキストローズの製造方 法}

$\begin{array}{rrr}\text { 特許出願公告 } & \text { 昭43-4414 } \\ \text { 公 } & \text { 告 } & \text { 昭 } 43.2 .17\end{array}$

出願人 コーン・プロダクッ・コンパニー 特許請求の範囲

1. 約 107 度乃至約 150 度 Cの温度を有するデキストロ 一ズ液を約 10 度乃至 40 度 $\mathrm{C}$ の温度を有しかつ擋拌されて いる結晶種床の上に噴霧し, 該液と該床とを短時間混合 域中で連続的に緊密に混合して該液中のデキストローズ を実質的に完全に結晶化させ，この実質的に結晶化した 生成物を約 32 度乃至 60 度 $\mathrm{C}$ の温度で上記混合域から, 約 5 度乃至 35 度 Cの温度を有する空気流中に放出するとと むにこの結晶化生成物を約 10 度乃至 40 度 $の$ 温度に調節 し，該液からの顕熱とデキストローズの結晶化熱とによ って結晶化生成物中の.残余の水分を蒸発させることから なり，しかして前記デキストローズ液は少なくとも約 90 パーセントのデキストローズおよび約88万至 98 パーセン トの乾燥物質を含有するものであり，また前記結晶種休 は本質的にデキストローズ結晶からなるものであること を特徽とする水易溶性でかつベーターデキストローズ含 量の損失に対して安定であるところの無水ベーターデキ ストローズを少なくとも約 40 パーセント含有する実質的 に無水のデキストローズを得る方法。

酒造用 $\alpha$ 化澱粉の製造法 特許出願公告 昭43-5693 公告 昭 43.3 .1

出願 人 松谷化学工業株式会社 特許請求の範团 
1・澱粉を酸及び還元剤溶液にて洗滌精製した後常法の 如く $\alpha$ 化することを特徴とする酒造用 $\alpha$ 化港粉の製造 法。

\section{ブドウ糖の製法}

特許出願公告＼cjkstart昭43-7834

公告昭43.3.25

出願人 エー・イー・スタレイー・マニユフ アクチュアリング・コンパニー

特許請求の範囲

1. 水性澌粉奬㓻液をアルフアミラーゼの作用で部分的 に加水分解し，この加水分解をアミログルコシダーゼの 作用で完結し，この加水分解生成物を㴓過することから なる測粉の酵素加水分解によるブドウ糖溶液を製造する 方法において部分加水分解物をアミログルコシダーゼで ブドウ糖に転化するに先立ってブドウ糖液中の不溶性物 の量を少くして滤過速度を速くするよ5に処理し，この 処理は事実上全ての測粉を液化するに充分な時間部分加 水分解物を約 $90 \sim 100^{\circ} \mathrm{C}$ に加熱すること生成する液体を 少なくとも $125^{\circ} \mathrm{C}$ に加熱すること $125^{\circ} \mathrm{C}$ 以上の温度とそ の温度に扣ける時間は最終ブドウ糖溶液の過度の着色を 避けるように制限されることからなることを特徴とする ブドウ糖の製法。

\section{澱粉用変性剂}

特許出願公告 昭43-7836

出願 人 モンサント・カンパニー 特許請求の範囲

1.スチレン一無水マレイン酸共重合体の半アミド半塩 を含有し且つ前記塩はアンモニウム拉よびアルカリ金属 からなる群から選択されたものを含有することを特徵と する澌粉用変性郕。

\section{澱粉の改変方法}

$\begin{array}{rrr}\text { 特許出願公告 } & \text { 昭 } 43-7837 \\ \text { 公 } & \text { 告 } & \text { 昭 } 43.3 .25\end{array}$

出願人、エフ・エムシー・コーポレーション 特許請求の範囲

1. 飳粉 $20 \sim 50$ 重量\%と激粉の重量に基ついて有効塩素 そ0.5〜 5.0重量\%与えるだけの二塩化シアヌル酸塩化合 物とを含有する水性スラリーを調製し，該ス、ラ、リ一を $\mathrm{pH} 8.0 \sim 9.0$ となし而して該スラリーを $32 \sim 80^{\circ} \mathrm{C}$ で, 前記の8.0〜9.0の $\mathrm{pH}$ の下に $2 \sim 4$ 時間の間保持するこ とよ9成ることを特徴とするペースト粘度を安定させか
つゲル化傾向を減らす測粉の改変方法。

\section{代用饀の製造法}

特許出願公告＼cjkstart昭43-8691

公告昭43.4.4

出 願人 松谷化学工業株式会社

特許請求の範国

1 ・澱粉を粒状のまま公知の架橋剤, 及びエーテル化又 はエステル化剂を用い, 激粉分子のグルコース単位 100 個当り, 架橋度が $0.2 \sim 2$ 個 程度水酸基の置換度が 3 個 以上となる如く架橋, 並にエーテル化又はエステル化せ しめ，これを食用色素に用いて着色するか又は着色せず に, これに架橋, 置換処理測粉の乾燥重量に対し約 2 倍 量の水又は食用色素を含む水の存在下, 甘味郕を加えて 加熱することを特徴とする代用饀の製造法。

2. 澱粉を粒状のまま公知の架橋剂, 及びエーテル化又 はエステル化剂を用い，測粉分子のグルコース単位 100 個当り, 架橋度が $0.2 \sim 2$ 個程度, 水酸基の置換度が 3 個以上となる如く架橋, 並にエーテル化せしめ, これを 食用色素にて着色し又はせずして水の存在下加熱膨潤さ せたものに，甘味剂を加えるか又は加えずしてドラムド ライヤ一等で乾燥することを特徴とする冷水又は甘味剂 を含む冷水で直ちに食用饀となる代用饀の製造法。

\section{葡葡糖その他澱粉糖製造法}

特許出願公告 昭43-12239

公 告 昭43.5.23

出 願人 松谷化学工業株式会社

特許請求の範囲

1 ・款類等の地上䬦粉に低温酸化能ある酸化郕を加えて その澱粉の粘度をその $5 \%$ 濃度の懸罍液を $85^{\circ} \mathrm{C}$ で加熱 糊化し $50^{\circ} \mathrm{C}$ で測定した值が $150 \sim 10 \mathrm{c} \cdot \mathrm{p} ・$ ・となる如く酸 化変性を与えた後, 該変性澱粉に対し液化酵素による液 化及び糖化酵素による糖化を順次に行らことを特徴とす る葡萄糖その他䬦粉糖製造法。

\section{穀類澱粉の酵素液化法}

特許出願公告 昭43-12240

公告昭43.5.23

出 願人日本食品化工株式会社

特許請求の範囲

1. 嵘類湘粉の䣦㜪液化に際し, 澌粉 $1 \mathrm{~kg}$ 当りカルシ ウムとして $1.5 \mathrm{~g}$ 乃至 $6 \mathrm{~g}$ 相当のカルシウム塩を添加し, pH 6.0 乃至 7.0 の間に調節しながら酵素液化を行らこ とを特徵とする款類澌粉の酵素液化法。 